Bravo, C., F. Cuscó, M. Borja Morales, and S. Mañosa. 2017. Diet composition of a declining steppe bird the Little Bustard (Tetrax tetrax) in relation to farming practices. Avian Conservation and Ecology 12(1):3. https://doi.org/10.5751/ACE-00938-120103

Copyright $(C) 2017$ by the author(s). Published here under license by the Resilience Alliance.

Research Paper

\title{
Diet composition of a declining steppe bird the Little Bustard (Tetrax tetrax) in relation to farming practices
}

\author{
Carolina Bravo $^{1}$, Francesc Cuscó ${ }^{1}$, Manuel B. Morales $^{2}$ and Santi Mañosa ${ }^{1}$ \\ ${ }^{1}$ Departament de biologia evolutiva, ecologia i ciències ambientals, Institut de Recerca de la biodiversitat (IRBio), Universitat de \\ Barcelona, Facultat de Biologia, ${ }^{2}$ Terrestrial Ecology Group (TEG).Departamento de Ecología. Facultad de Ciencias, \\ Universidad Autónoma de Madrid. Madrid
}

\begin{abstract}
Foraging strategies and diet selection play an essential role in individual survival and reproductive success. The study of feeding ecology becomes crucial when it concerns endangered species such as the Little Bustard (Tetrax tetrax), whose populations are suffering strong declines as a consequence of agricultural intensification. Despite the fact that several populations are overwintering in areas affected by agricultural transformation, nothing is known about how feeding behavior responds to these changes. We studied for the first time the winter diet composition of the Little Bustard in Spain and compared it between areas with two different farming systems: dry and irrigated farmland. Diet was studied through the micro-histological analysis of 357 droppings collected in 16 locations across the wintering range of the Little Bustard in Spain. Up to 62 plant species were identified. Most consumed species were cultivated legumes $(46.7 \%)$ and dicotyledon weeds $(45.6 \%)$, while monocotyledons were scarcely consumed $(7.7 \%)$. Diet composition differed significantly between dry and irrigated farmland areas. In irrigated areas, diet was mainly composed of legumes, in particular alfalfa (Medicago sativa). In contrast, in dry farmland areas diet was more diverse, composed mainly of weeds (Compositae, Papaveraceae, and Cruciferae) and also cultivated legumes, particularly vetch (Vicia sativa). These results suggest that legume crops could be an effective measure to improve habitat quality in areas with scarce food resources. However, in the case of irrigated areas, the strong reliance on alfalfa could make the Little Bustard more vulnerable to changes in land use. This study is the first step to understand the winter trophic requirements of the endangered Little Bustard, but further research is necessary to understand the food requirements of this species during the entire annual cycle.
\end{abstract}

\section{Régime alimentaire d'un oiseau de steppe en diminution, l'Outarde canepetière (Tetrax tetrax), en lien avec les pratiques agricoles}

RÉSUMÉ. Les stratégies d'alimentation et le choix du régime alimentaire jouent un rôle essentiel dans la survie et le succès reproducteur d'un individu. L'étude de l'écologie alimentaire revêt une importance cruciale lorsqu'il s'agit d'une espèce en voie de disparition telle que l'Outarde canepetière (Tetrax tetrax), dont les populations subissent des diminutions très marquées en raison de l'intensification des pratiques agricoles. Malgré le fait que plusieurs populations hivernent dans des endroits où se produisent des changements agricoles, on ne sait pas comment les oiseaux adaptent leur comportement alimentaire face à ces changements. Nous avons étudié pour la première fois la composition du régime alimentaire hivernal de l'Outarde canepetière en Espagne, et l'avons comparée dans deux systèmes agricoles : des terres cultivées sèches ou irriguées. Le régime alimentaire a été examiné au moyen de l'analyse micro-histologique de 357 fèces récoltées sur 16 sites répartis dans l'aire d'hivernage de l'outarde en Espagne. Nous avons identifié 62 plantes. La plupart des espèces végétales consommées étaient des légumineuses cultivées (46,7\%) ou des mauvaises herbes dicotylédones $(45,6 \%)$; les monocotylédones n'ont été que très peu consommées $(7,7 \%)$. La composition du régime alimentaire a grandement différé entre les secteurs de terres sèches ou irriguées. Dans les secteurs de terres irriguées, le régime était principalement composé de légumineuses, surtout de luzerne (Medicago sativa). À l'opposé, dans les secteurs de terres sèches, le régime était plus diversifié; il était essentiellement composé de mauvaises herbes (Compositae, Papaveraceae et Cruciferae) et de légumineuses cultivées, surtout de vesce (Vicia sativa). Nos résultats indiquent que la culture de légumineuses pourrait représenter une mesure efficace pour améliorer la qualité de l'habitat dans les secteurs où les ressources alimentaires se font rares. Toutefois, dans le cas des secteurs irrigués, la forte dépendance à la luzerne pourrait rendre cette outarde particulièrement vulnérable aux changements dans l'utilisation des terres. La présente étude est une première étape dans la compréhension des besoins trophiques de l'Outarde canepetière en hiver, et d'autres recherches sont nécessaires si l'on veut comprendre ses besoins alimentaires durant la totalité de son cycle annuel.

Key Words: dry farmland system; extensive farmland; foraging behavior; irrigated system; legumes; Little Bustard

Address of Correspondent: Carolina Bravo, Facultat de Biologia, Universitat de Barcelona, Avinguda Diagonal 643, 08028, Barcelona, Spain, carolina.bravo.parraga@gmail.com 
Table 1. Averaged $( \pm \mathrm{SD})$ habitat composition and configuration of the study sites grouped by irrigated and dry farmland areas.

\begin{tabular}{|c|c|c|c|c|}
\hline & $\begin{array}{l}\text { Irrigated areas } \\
(\mathrm{n}=8)\end{array}$ & $\begin{array}{l}\text { Dry farmland areas } \\
\qquad(\mathrm{n}=8)\end{array}$ & Mann Whitney U-test & $p$ \\
\hline \multicolumn{5}{|l|}{ Habitat configuration } \\
\hline Shannon index habitat & $1.6 \pm 0.2$ & $1.5 \pm 0.3$ & 54 & 0.024 \\
\hline Field size (ha) & $1.3 \pm 1.4$ & $2.5 \pm 1.6$ & 9 & 0.015 \\
\hline \multicolumn{5}{|l|}{ Land uses $(\%)$} \\
\hline Fallow & $4.0 \pm 2.6$ & $6.1 \pm 6.2$ & 27 & 0.645 \\
\hline Sown cereal & $9.4 \pm 5.1$ & $50.8 \pm 18.0$ & 1 & $<0.001$ \\
\hline Ploughed & $31.0 \pm 18.6$ & $15.0 \pm 11.5$ & 50 & 0.065 \\
\hline Maize stubble & $11.5 \pm 7.5$ & -- & & \\
\hline Cereal stubble & $2.0 \pm 3.7$ & $26.1 \pm 25.3$ & 9.5 & 0.018 \\
\hline Fruit-tree orchard & $18.3 \pm 14.9$ & -- & & \\
\hline Legume crops $^{\dagger}$ & $19.4 \pm 10.2$ & $0.9 \pm 1.6$ & 64 & $<0.001$ \\
\hline Olive and vineyard & $3.1 \pm 3.2$ & $1.2 \pm 1.9$ & 47 & 0.122 \\
\hline
\end{tabular}

\section{INTRODUCTION}

The Little Bustard, Tetrax tetrax, is a medium-sized Paleartic steppe bird from the Otididae family that has suffered a strong population decline during the last century. It is classified as "near threatened" at the global scale and "vulnerable" in Europe (BirdLife International 2004, 2016). Nowadays, a significant proportion of the world's population is concentrated in the Iberian Peninsula (García de la Morena et al. 2006, Iñigo and Barov 2010), where it inhabits extensive pastures and cereal farmland (Martínez 2008). Studies determining habitat selection and population trends suggest that the species population decline has been mainly caused by recent agricultural changes affecting their foraging habitats (Goriup 1994, Wolff et al. 2001, Bretagnolle et al. 2011). Land irrigation is one of the most important alterations in agricultural farmland, mainly through crop change and intensification, and it is considered one of the major threats for the conservation of this steppe bird (Brotons et al. 2004). The negative effect of agricultural transformation through irrigation schemes has been reported in Little Bustard and several steppe species (Tella and Forero 2000, Brotons et al. 2004, De Frutos et al. 2015). However, although landscape transformations and other potential threats in their areas are thought to contribute to this decline, it is unknown how the feeding ecology of Little Bustards is affected by these changes. In fact, although there are numerous studies on Little Bustard ecology, little is known about the species' diet. Little Bustards are omnivorous, their diet consisting mainly of green plant material followed by arthropods and seeds (Cramp and Simmons 1980). The only previous studies on the diet of the Little Bustard were carried out in Russia during the breeding and postbreeding seasons (Shlyakhtin et al. 2004) or focused only on the animal component (Jiguet 2002). Most studies of Little Bustard ecology have focused on breeding and postbreeding ecology (Martínez 1994, Salamolard and Moreau 1999, Wolff et al. 2001, 2002, Silva et al. 2007, Morales et al. 2008, 2013, Traba et al. 2008, Delgado et al. 2010), but little information is available on its habitat requirements during winter (but see Silva et al. 2004, García de la Morena 2016), when it is congregated in large flocks and food availability could be a critical factor. Indeed, winter diet composition, which is presumably mostly herbivorous, is completely unknown.

We studied for the first time the winter diet composition of the Little Bustard in two of the main wintering areas for the species in Spain (Ebro valley and Southern Plateau; García de la Morena et al. 2006). Furthermore, we explored the effects of irrigation schemes on diet composition. To do this, we compared the diet composition between areas under two different farming systems: dry and irrigated farmland. Our studied dry farmland areas were characterized by cereal crops in a two-year rotation system, which generates a mosaic-like agricultural landscape of stubbles, ploughs, fallows, and sown cereal, along with to a lesser extent, other crops such as legumes, olive groves, and vineyards. On the contrary, irrigated farmland areas were dominated by intensively managed herbaceous crops, e.g., maize, alfalfa (Medicago sativa), and irrigated cereal, along with fruit-tree orchards, and characterized by smaller field sizes, and thus greater amount of field margins, than dry farmland (Table 1). Based on the different characteristics of each system, we hypothesized that Little Bustards should change their feeding behavior with the conditions of each agroecosystem. On the one hand, because the Little Bustard strongly selects legume crops (Martínez 1994, Salamolard and Moreau 1999, Bretagnolle et al. 2011), we expected that their diet should be mainly composed of legumes, especially in irrigated landscapes where legume crops of alfalfa are highly available. On the other hand, optimal foraging theory proposes that as a preferred resource becomes scarce, individuals tend to open their trophic niche behaving as opportunistic (Stephens and Krebs 1986), hence in areas with low legume availability such as dry farmland, we expected that diet diversity of Little Bustards should be higher. We provide a more comprehensive understanding of the winter requirements of the Little Bustard, and other herbivorous birds inhabiting cultivated farmland in a rapidly changing environment. In this context, the study of the feeding behavior of an endangered species could be 
Fig. 1. Map of the study area showing the irrigated sampling sites (1: Anglesola; 2: Arbeca; 3: Castellnou de Seana; 4: Torregrossa; 5: Miralcamp; 6: El Poal; 7: Sidamon; 8: La Puebla de Montalbán) and the dry farmland sampling sites (9: Campo de Calatrava; 10: Campo Real; 11: Valdepiélagos; 12: Cobeña; 13: Daganzo de Arriba; 14: Valdetorres de Jarama; 15: Villanueva de la Torre; 16: Torrejón de Velasco). Agrarian land-use composition in $1500 \mathrm{~m}$ buffers around the point of dropping collection is shown for two of the 16 sampling points (Torrejón de Velasco and Arbeca), as an example of each farmland system.
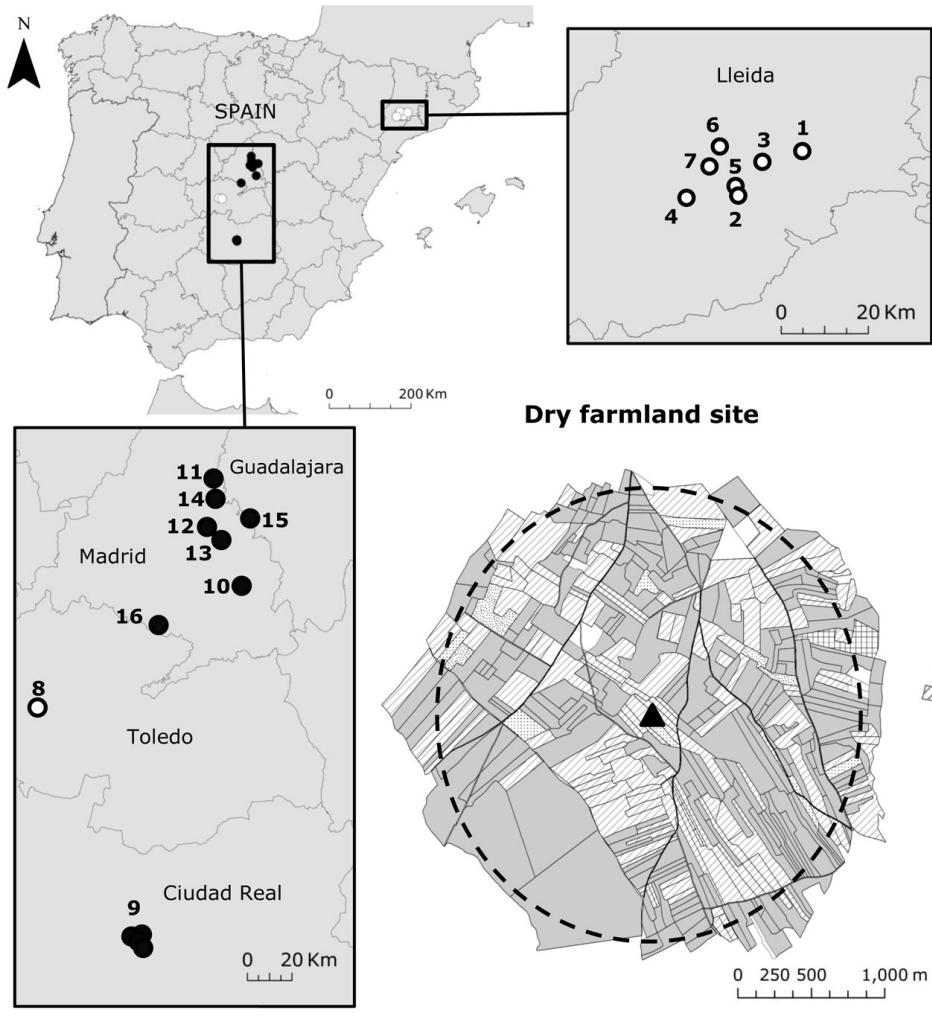

O Irrigated sampling site

- Dryland sampling site

$\Delta$ Point of droppings collection

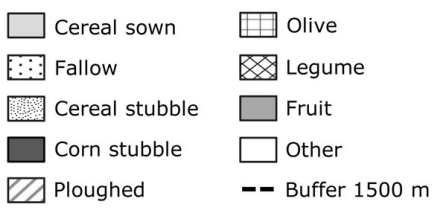

Dry farmland site
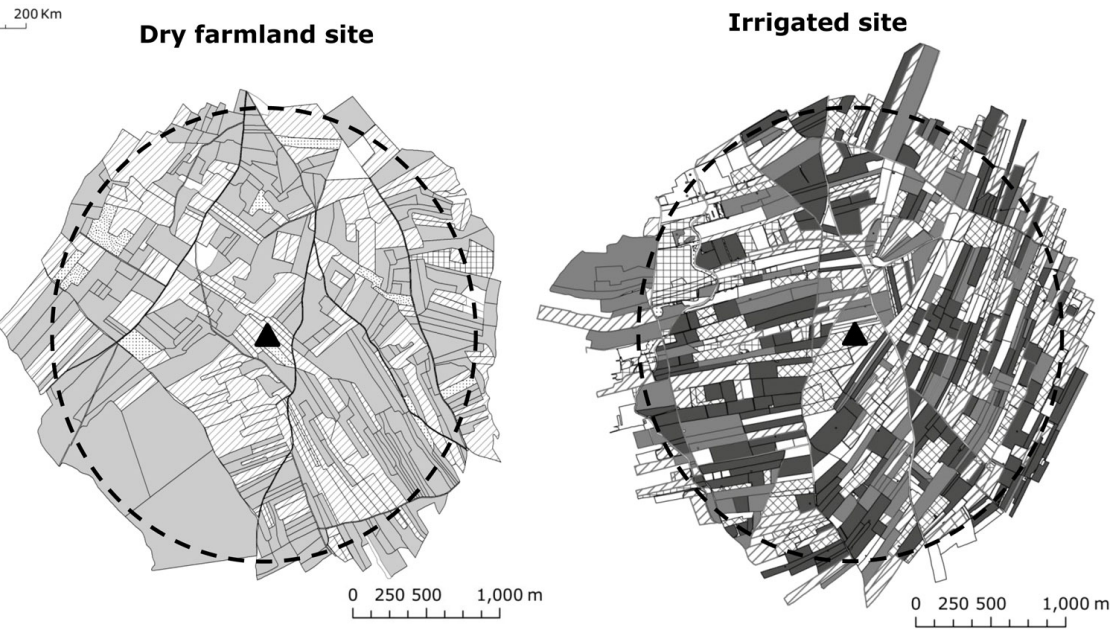

an essential tool to reverse its negative trend. A precise knowledge of the diet of species living in changing environments can help to identify key environmental resources for designing reliable conservation strategies.

\section{METHODS}

\section{Study area}

The study was conducted on irrigated and dry wintering farmland areas within the Spanish Little Bustard range, where populations of the species have been intensively studied (Fig. 1; García de la Morena et al. 2007, Ponjoan et al. 2012, Tarjuelo et al. 2013). Irrigated farmlands were covered by a large variety of crops, although dominated by winter-sown cereal and maize crops, as well as alfalfa fields and fruit-tree orchards (Table 1). Sampling of these irrigated areas was carried out in seven locations of Lleida Plains (Anglesola, Arbeca, El Poal, Torregrossa, Castellnou de Seana, Sidamon, Miralcamp), situated on the northeastern edge of the Ebro Valley and dominated by small fields linked to gravityirrigated agriculture, and one location in the Tagus valley (La Puebla de Montalbán) sited in the Iberian Southern Plateau, dominated by largepivot-irrigated fields. Dry farmland was mostly dedicated to cereal production $(>80 \%)$, with some olive groves, vineyards, and leguminous crops (Vicia sativa and Vicia spp.; Table 1). Sampling of the dry farmland area was carried out in eight locations of the Southern Plateau in Madrid, Guadalajara, and Ciudad Real provinces (Valdepiélagos, Valdetorres de Jarama, Cobeña, Daganzo de Arriba, Campo Real, Villanueva de la Torre, Torrejón de Velasco, Campo de Calatrava).

\section{Diet analysis}

The diet was studied using 357 droppings collected in late November-January between 2003-2013 (Table A1.1.), in the above-mentioned eight irrigated and eight dry farmland sites within the study area (Fig. 1). On each site, fresh droppings were collected at roosting sites at dawn from cereal sown $(25.5 \%)$, stubble (37.7\%), and leguminous crops (36.8\%). Each morning, we randomly collected $13.2 \pm 5.1$ (mean $\pm S D$, range: $6-25)$ fresh individual droppings per flock (127.5 \pm 182.1 individuals per flock, range: 13 - 500). To avoid pseudo-replication, we collected fewer droppings than individuals per flock and only those that were at least $10 \mathrm{~m}$ apart. Each dropping was individually stored in a labeled bag, oven-dried at $60^{\circ} \mathrm{C}$ within 48 hours, and weighed afterward (accuracy: $0.001 \mathrm{~g}$ ).

Each dropping was partitioned into green plant material, arthropods, and seeds with the aid of a binocular microscope 
$(20 \times)$. These components were weighed separately and the dry weight proportion calculated per dropping. Plant species were identified and quantified by micro-histological techniques using our reference collection of tissues from the study area (Bravo et al. 2016; C. Bravo, O. Jordi, F. Cuscó and S. Mañosa 2016, unpublished data). From each sample, 80 fields, i.e., the visible circle that is observed through the microscope, were examined with a microscope $(40 \times)$, recording the presence or absence of each plant species. We calculated the diet composition as the occurrence percentage of each plant species per dropping, $\mathrm{OD}=$ $\mathrm{n}_{i}{ }^{*} 100 / 80$, where $\mathrm{n}_{i}$ is the number of microscope fields in which species $i$ occurred in the 80 microscope fields. All identified plants and their occurrence percentage in the diet (OD) are shown in Table A1.2.

\section{Habitat configuration and land uses}

To describe habitat configuration and proportion of land-use types of the study area, we delimited a $1500 \mathrm{~m}$ buffer around each dropping collection site $(n=16)$. Based on ecology movement of the Little Bustard in the study area (F. Cuscó and S. Mañosa 2016, unpublished data, personal observation), we assumed that this buffer provides characteristic information of the feeding areas on each sampling point. Indeed, habitat configuration and proportion of land-use types were also calculated for buffers of $1000 \mathrm{~m}$ and $500 \mathrm{~m}$ radius to determine whether results were sensitive to radius choice. Because similar results were obtained, only results of $1500 \mathrm{~m}$ radius are presented. In each buffer area, the habitat composition was assessed by recording the land-use type in each field and calculating the proportion of different landuse types using ArcView 10.2.2 (ESRI 2014). The land-use types considered were sown cereal crops, cereal stubbles, maize stubbles, ploughs, fallows, irrigated legume crops (Medicago sativa), dry legume crops (Vicia sativa and Vicia spp.), olive and vineyards, fruit-tree orchard crops, and nonused land (shrubland, infrastructures, etc.; Table 1). Farmers usually plow stubble during this period. To record the land-use types actually available for foraging Little Bustards, land-use data were collected on the same day or a few days around the date of dropping collection. Habitat configuration on the same buffer areas were estimated using FRAGSTATS 4.2 (McGarigal et al. 2012) by calculating the following variables: (i) habitat diversity (SHDI; computed using the Shannon index and considering the proportional abundance of each land-use types); and (ii) mean field size (ha) as a measure of edge density.

\section{Statistical analysis}

We examined the overlap in diet composition (percentage of each plant species per dropping) between and within dry and irrigated farmland areas using nonmetric multidimensional scaling (NMDS). NMDS is an ordination technique that uses a BrayCurtis matrix of ranked similarities and displays samples in lowdimensional space while retaining as nearly as possible the similarity rankings between groups. We chose this method for the following reasons: (i) avoids the assumption of linear relationships among variables; (ii) nonnormal and nonlinear data can be used; and (iii) the ordination based on ranks relieves the "zero-trucation problem" (McCune and Grace 2002). The stress criterion was used to evaluate goodness of fit for the final NMDS model. NMDS results were considered to represent a useful model if two-dimensional stress was less than 0.2 (Kruskal 1964, Clarke
1993). We then used analysis of similarities (ANOSIM), a nonparametric test that uses permutations to calculate significance between groups, to determine if there were differences in diet composition of dry and irrigated farmland area. The test statistic was the global $\mathrm{R}$, which can range from -1 to +1 , with a value close to -1 indicating that the variation within groups is higher than the variation between groups and a value close to +1 indicating that the variation between groups is higher than the variation within groups (Clarke 1993). If a significant result ( $\mathrm{p}<$ 0.05 ) was obtained using ANOSIM, we used analysis of similarity percentages (SIMPER) to determine which particular plant species were responsible for the dissimilarity between areas (Clarke 1993). All analyses above were conducted with vegan package for R 2.15 (Oksanen et al. 2013).

Diet diversity in the droppings was calculated using the Shannon diversity index $H^{\prime}=-\sum(p i \cdot \ln p i)$, where $p i$ is the proportion of species $i$ (plant, animal and seed species) per dropping. Differences in diet diversity between dry and irrigated farmland areas were analyzed by the nonparametric Mann-Whitney U test, based on the mean diversity per sampling site. Also, differences of diet diversity among sampling sites of dry farmland and among sampling sites of irrigated farmland were analyzed by KruskalWallis test followed by Dunn's post hoc multiple comparison test. Differences in habitat configuration variables, land-use availability, and differences in dry weight of droppings in the two agroecosystems were analyzed by means of a nonparametric Mann-Whitney $U$ test. Results are reported as mean \pm SD in the text and tables; and mean $\pm \mathrm{SE}$ in the figures.

\section{RESULTS}

Dry weight of droppings was $0.95 \pm 0.86 \mathrm{~g}$, showing no differences between the two agrosystems (Mann-Whitney $U=16573, p=$ 0.43). The dry weight proportions of droppings were $99.998 \%$ of green plant material, $0.001 \%$ of arthropod, and $0.001 \%$ of seeds. Most droppings were composed exclusively of green plant material $(96.4 \%$ ), whereas only $2.8 \%$ and $0.8 \%$ of total droppings contained arthropod and seed remains, respectively.

Up to 62 plant species were identified, with an average of $6 \pm 4$ species per dropping and $15.8 \pm 9.8$ species per sampling area $(\mathrm{n}$ $=16)$. Overall, most species were cultivated legumes $(46.7 \%$ of diet composition) and weeds (45.6\% of diet composition), with reduced presence of graminoid species $(7.7 \%$ of diet composition; Table A1.1). Arthropod remains corresponded to Coleoptera and Hymenoptera (Formicidae), 2.2\% and $0.6 \%$ of droppings, respectively. Seeds belonged to undetermined weeds, but did not belong to any cultivated cereal or legume.

Among plants, the high consumption of cultivated legumes was highlighted ( $83.2 \%$ of total legumes), mainly Medicago sativa and Vicia sativa. Among weeds, Compositae, Papaveraceae, and Cruciferae were the most frequent families consumed (Table A1.1). The main species eaten were Anacyclus clavatus, Papaver rhoeas, Capsella bursa-pastoris, Diplotaxis erucoides, and Convolvulus arvensis (Table A1.2). Regarding graminoid plant species, Hordeum vulgare was the most common in the diet of Little Bustard (4.9\% of diet composition; Table A1.2).

The NMDS analysis of the diet composition showed a clear spatial separation between diet composition of dry farmland and irrigated areas (Fig. 2). This was statistically verified with 
ANOSIM test, which showed a significant difference in the degree of separation between the two assemblages $(\mathrm{R}=0.56, \mathrm{p}<0.05)$. An additional post hoc analysis, SIMPER, found that the $38 \%$ of the dissimilarity between the assemblages was attributed to the proportion of Medicago sativa, $11.7 \%$ attributed to Capsella bursa-pastoris, and $6.8 \%$ to Vicia sativa. Among dry farmland sampling sites, ANOSIM test showed no significant difference in the degree of separation between assemblages of dry farmland sites $(\mathrm{R}=-0.011, \mathrm{p}>0.05)$. Also among irrigated sampling sites, ANOSIM test showed no significant difference in the degree of separation between assemblages of irrigated sites $(R=-0.072, p$ $>0.05)$.

Fig. 2. Nonmetric multidimensional scaling (NMDS) plot representing diet similarity for dry farmland (dark grey) and irrigated areas (light grey).

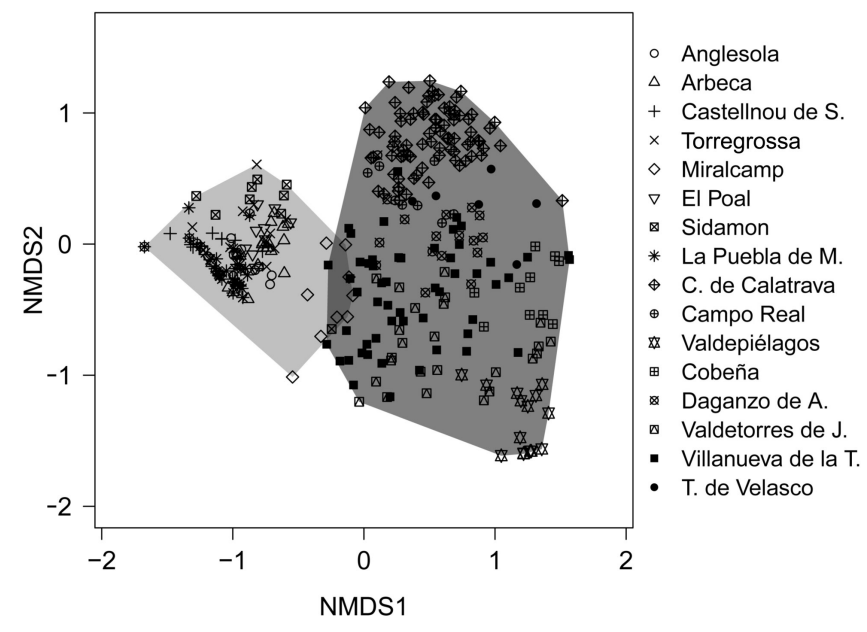

Diet diversity was significantly higher in dry farmland area ( $\mathrm{H}^{\prime}$ : $1.34 \pm 0.47)$ than in irrigated area ( $\mathrm{H}^{\prime}: 0.59 \pm 0.33$, Mann-Whitney $\mathrm{U}=2938.5, \mathrm{p}<0.001)$. Diet in irrigated areas mainly consisted of legumes $(67.1 \pm 28.3 \%$ of diet composition), followed by Cruciferae (25.2 $25.5 \%$ of diet composition; Fig. 3 ), whereas in dry farmland area diet was characterized by the presence of species from Leguminosae, Compositae, Papaveraceae, and Cruciferae species (Fig. 3). Among irrigated areas, diet diversity was significantly different between sampling sites $\left(\mathrm{H}_{7}=131.5, \mathrm{p}\right.$ $<0.05$ ); being Arbeca and El Poal significantly more diverse than Anglesola, Castellnou de Seana, and La Puebla de Montalbán (Dunn's test $\mathrm{p}<0.05$ ). Whereas among dry farmland areas, diet diversity was also significantly different between sampling sites $\left(\mathrm{H}_{7}=39.4, \mathrm{p}<0.05\right)$; being Campo de Calatrava and Campo Real significantly more diverse than the remaining sites, except Torrejón de Velasco (Dunn's test $\mathrm{p}<0.05$ ).

\section{DISCUSSION}

In agreement with previous studies conducted in France and Russia (Jiguet 2002, Shlyakhtin et al. 2004) on the diet in the breeding and postbreeding seasons, the winter diet of the Little Bustard in Spain fundamentally consisted of green plant material, mainly cultivated legumes $(46.7 \%)$ and weeds $(45.6 \%)$. Monocotyledon species were only seldom consumed $(<8 \%)$, in accordance with what has been reported for related species, such as the Great Bustard (Lane et al. 1999, Bravo et al. 2016). This low consumption is remarkable because the availability of wild or cropped monocotyledons is very high in the studied farmland habitats, and is probably the consequence of its low digestibility and nutritional value compared to weeds and legumes (Smith et al. 1972).

Fig. 3. Percentage (mean $\pm S E)$ of the main plant families in the diet of Little Bustards (Tetrax tetrax) in irrigated (white columns) and dry farmland areas (grey columns) in Spain. Infrequent families (Caryophyllaceae, Boraginaceae, Dipsacaceae, Euphorbiaceae, Malvaceae, Plantaginaceae, Primulaceae, Resedaceae, Rubiaceae, Scrophulariaceae) have been grouped in the "other" category.

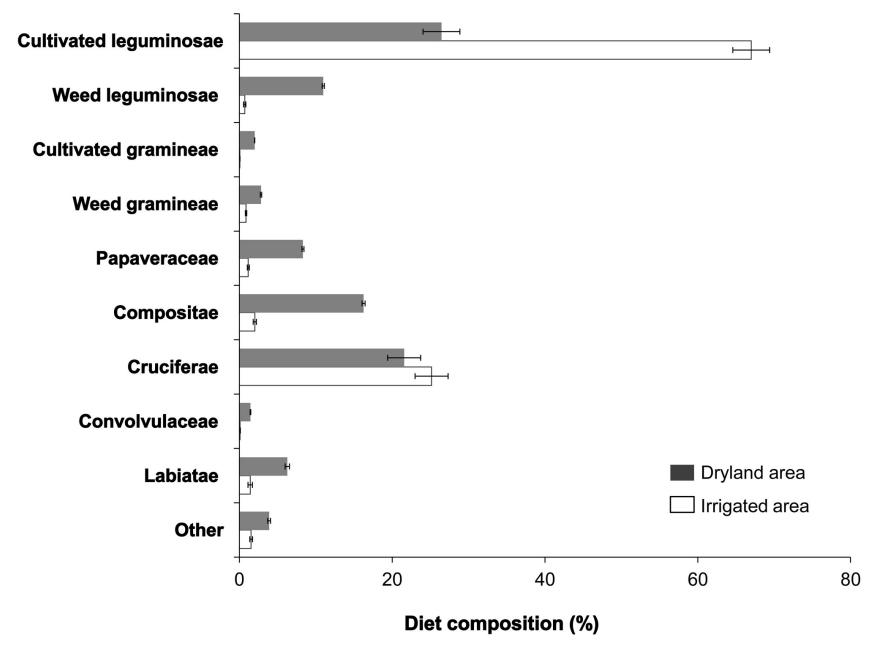

Microhistological analysis is a method widely used to assess diet composition of herbivorous species (La Morgia and Bassano 2009, Blanco-Fontao et al. 2010, Whitney et al. 2011, Kobayashi and Takatsuki 2012, Xu et al. 2012, Freschi et al. 2014). However, results from microhistological analysis of droppings could have a potential bias derived from differential digestibility of plant species. For example, graminoids or ligneous species are generally over-represented in faecal samples (Vavra and Holechek 1980, Alipayo et al. 1992). Our results showed that diet consisted mainly of dicotyledon weeds, with smaller proportion of graminoids. Therefore, unless there are large differences in digestibility between dicotyledon weed species of our study area, our results should not differ significantly from the composition of true diet. In any case, any potential bias should not affect the comparisons between farming systems, which supports the reliability of our conclusions. On the other hand, although our sample of droppings was collected over a long period of time, sample size did not allow to test for interannual variation. Nevertheless, this study is the first step to understand the trophic requirements of Little Bustards and further studies are needed to address the changes in diet across years as agricultural intensification and land-use changes are the main threat to this species.

Cultivated legumes were an important winter food resource for Little Bustard in both irrigated (67\%, alfalfa) and dry farmland (26\%, mainly vetch Vicia sativa). This was not surprising on irrigated farmland, where alfalfa covers up to $19 \%$ of land (Table 
1), but it was somehow unexpected on dry farmland, with only a meagre $1 \%$ of legume crop availability (Table 1). This indicates a strong preference for feeding on legumes, as already suggested by the reported selection of legume crop areas exhibited by the Little Bustards (Martínez 1994, Salamolard and Moreau 1999, Bretagnolle et al. 2011).

In spite of this apparent preference for cultivated leguminous plants, noncultivated plants were also very important in the winter diet of the Little Bustard. This dominance of weeds was remarkable on dry farmland, where Anacyclus clavatus, Papaver rhoeas, Diplotaxis erucoides, and Capsella bursa-pastoris formed the bulk of the diet. But it was somehow surprising in irrigated habitats, where the Little Bustards consumed a remarkable $32 \%$ of noncultivated plants despite that alfalfa crops seemed to provide a virtually unlimited high quality food supply. We hypothesized that nutrient requirement cannot be met from a single plant species (Stephens and Krebs 1986, Raubenheimer and Simpson 1997) and, consequently, Little Bustards try to incorporate a greater variety of plant species in their winter diet to meet a complete range of nutrient needs.

The fact that there were no significant differences in diet composition between sampling sites among irrigated areas, or among dry farmland areas, suggests a consistent feeding behavior within each agroecosystem, regardless of the region (Ebro Valley or Southern Plateau), hence highlighting the robustness of the pattern described and indicating that diet composition varied between agrarian systems rather than between regions. Likely these differences in diet were the consequence of different landuse availability between agrosystems (Table 1). On dry farmland areas, diet composition was much more diverse, being composed mainly of weeds and legumes. These plants were probably provided by cereal stubble (Table 1), which hold higher availability of weeds (Ponce et al. 2014; personal observation). Also, the higher global dietary diversity on dry farmland areas was both the result of a higher between and within site variation (Figs. 2 and 3, Table A1.1). At some sites, such in Valdepiélagos and Valdetorres, cultivated legumes in diet were dominant (Table A1.1), because in these areas there was about $2 \%$ of surface occupied by $V$. sativa crops provided by the agri-environmental scheme programs (Ponce et al. 2014). In other areas, where these crops were less available, diet was more diverse, based on a mixture of legumes and weeds (Campo Real, Villanueva de la Torre), cereals and weeds (Cobeña), or mainly on weeds (Campo de Calatrava, Daganzo de Arriba, and Torrejón de Velasco), likely depending on the land-use composition on each site. The Little Bustard therefore seems to follow the prediction of optimal foraging theory, which proposes that diet diversity decreases as the abundance of the preferred resource increases (Stephens and Krebs 1986). On the contrary, in irrigated areas, despite having higher edge density and habitat diversity (Table 1), which could counteract a potentially constrained diet by providing a wider variety of food resources (Ottens et al. 2014), the dietary spectrum and diet diversity were always low, mainly composed of legumes alfalfa or, in one location (Miralcamp), cruciferae (Figs. 2 and 3, Table A1.1). Therefore, we cannot preclude the possibility that the low diversity in the diet of Little Bustard in irrigated farmland is reflecting the reduced availability of alternative resources as a consequence of agricultural intensification as has been reported in other species (Britschgi et al. 2006, Moorcroft et al. 2006, Cardador et al. 2012).

Although cultivated legumes seem to provide a good food resource for Little Bustards in winter, we would like to warn about some potential drawbacks of this dependence. First, the strong reliance on legumes as a winter food resource, particularly in irrigated areas, could result in a vulnerable system, being very sensitive to changes in land uses, because of the lack of alternative suitable food resources. Alfalfa crops seem to act as a habitatisland surrounded by unsuitable habitat for Little Bustards, such as fruit-tree orchard and ploughs (Silva et al. 2004), hence a decrease in the surface of alfalfa or isolation from each other could entail the abandonment of the area by the Little Bustard (Saunders et al. 1991, Brotons et al. 2004), as has been recently described by Morales et al. (2015) for the Tagus valley. Second, the benefits of a diverse diet on the fitness, growth, or survivorship has been reported for several species, particularly herbivorous ones (Lefcheck et al. 2013) so it is likely that a narrow diet composed mainly of alfalfa does not meet the complete range of nutrients needed by Little Bustards. In fact, as stated above, our results suggests that, even in alfalfa-dominated areas, a high proportion of weeds are included in the diet, suggesting that the Little Bustard needs to equilibrate their winter diet with a variety of plants. Finally, alfalfa monocultures are intensively managed crops, involving the use of high amounts of pesticides (Barker et al. 1980, Almacellas and Perdiguer 2007, Cantero and Moncunill 2012). It is well known that the use of these compounds has direct or indirect effects on avian wildlife, compromising bird survival or breeding success because of intoxication by the ingestion of contaminated food, soil, or water (Fry 1995, Lemly et al. 2000). Thus, the potential negative effects that a high reliance on alfalfa as a winter food resource may have on the Spanish Little Bustard population and those of other farmland birds deserve further attention from an ecological, nutritional, and toxicological point of view. In the meantime, although the effectiveness of providing legume crops as a measure to increase habitat quality and carrying capacity for bustards in agricultural landscape has been well established (Wolff et al. 2001, Ursúa et al. 2005, Bretagnolle et al. 2011, Kovács-Hostyánszki and Báldi 2012, Ponce et al. 2014), we suggest that these crops should be included within a web of a diverse habitat matrix providing different suitable and complementary habitats such as fallow land (Silva et al. 2004) to supply alternative and varied food resources.

To summarize, our results show that Little Bustards show a great trophic plasticity, being able to change their foraging behavior with the conditions prevailing on each agrarian system. The conservation of this species in Spain requires the adequate management of agricultural farmland aiming to meet its food requirements. In winter, this would involve providing diversified landscapes, containing large amounts of wild or cropped legumes, but also many weeds to complement the diet. In areas dominated with cultivated legumes, fallow land should be promoted. On the contrary, on cereal- and fallow-dominated areas, plots of legume crops should be provided. Finally, practices associated to the intensive treatment of fallows such as repeated tillage of rotatory fallows should be avoided. This study is the first step to improve our knowledge about feeding behavior of the Little Bustard in a changing farmland environment. However, there is still much 
work to be done to understand to what extent the variable availability of trophic resources might explain the decline of Little Bustard populations in Spain. This requires improving our knowledge of the species feeding behavior during the breeding season and identifying the trade-offs between food intake and fitness.

Responses to this article can be read online at: http://www.ace-eco.org/issues/responses.php/938

\section{Acknowledgments:}

We thank C. Palacín, R. Tarjuelo, E. García de la Morena, P. Delgado, F. Mougeot, F. Casas, and A. Ortiz for their valuable help during field work. Also we thank N. Ponsà and O. Jordi for their contribution to the laboratory tasks. This study was financially supported by Aigües del Segarra-Garrigues, S. A., as well as project CGL2009-13029/BOS of the Spanish Ministry of Science, and contributes to the REMEDINAL 3 (S2013/MAE-2719) network of the CAM. We thank two anonymous reviewers for their comments.

\section{LITERATURE CITED}

Alipayo, D., R. Valdez, J. L. Holechek, and M. Cardenas. 1992. Evaluation of microhistological analysis for determining ruminant diet botanical composition. Journal of Range Management 45:148-152. http://dx.doi.org/10.2307/4002773

Almacellas, J., and A. Perdiguer. 2007. Las plagas de la alfalfa y su control químico y biológico. Vida Rural 246:22-26.

Barker, R. J., Y. Lehner, and M. R. Kunzmann. 1980. Pesticides and honey bees: nectar and pollen contamination in alfalfa treated with dimethoate. Archives of Environmental Contamination and Toxicology 9:125-133. http://dx.doi.org/10.1007/BF01055368

BirdLife International. 2004. Birds in Europe: population estimates, trends and conservation status. BirdLife. International, Cambridge, UK.

BirdLife International. 2016. Species factsheet: Little Bustard Tetrax tetrax. BirdLife International, Cambridge, UK. [online] URL: http://datazone.birdlife.org/species/factsheet/22691896

Blanco-Fontao, B., A. Fernández-Gil, J. Ramón Obeso, and M. Quevedo. 2010. Diet and habitat selection in Cantabrian Capercaillie (Tetrao urogallus cantabricus): ecological differentiation of a rear-edge population. Journal of Ornithology 151:269-277. http://dx.doi.org/10.1007/s10336-009-0452-9

Bravo, C., C. Ponce, L. M. Bautista, and J. C. Alonso. 2016. Dietary divergence in the most sexually size-dimorphic bird. Auk 133:178-197. http://dx.doi.org/10.1642/AUK-15-206.1

Bretagnolle, V., A. Villers, L. Denonfoux, T. Cornulier, P. Inchausti, and I. Badenhausser. 2011. Rapid recovery of a depleted population of Little Bustards Tetrax tetrax following provision of alfalfa through an agri-environment scheme. Ibis 153:4-13. http://dx.doi.org/10.1111/j.1474-919X.2010.01092.x
Britschgi, A., R. Spaar, and R. Arlettaz. 2006. Impact of grassland farming intensification on the breeding ecology of an indicator insectivorous passerine, the Whinchat Saxicola rubetra: lessons for overall alpine meadowland management. Biological Conservation 130:193-205. http://dx.doi.org/10.1016/j.biocon.2005.12.013

Brotons, L., S. Mañosa, and J. Estrada. 2004. Modelling the effects of irrigation schemes on the distribution of steppe birds in Mediterranean farmland. Biodiversity and Conservation 13:1039-1058. http://dx.doi.org/10.1023/B:BIOC.0000014468.71368.35

Cantero, C., and J. Moncunill. 2012. Sistemas agrícolas de la plana de Lleida: Descripción y evaluación de los sistemas de producción en el área del canal Segarra-Garrigues antes de su puesta en funcionamiento. Universitat de Lleida, Lleida, Spain.

Cardador, L., E. Planas, A. Varea, and S. Mañosa. 2012. Feeding behaviour and diet composition of Marsh Harriers Circus aeruginosus in agricultural landscapes. Bird Study 59:228-235. http://dx.doi.org/10.1080/00063657.2011.648165

Clarke, K. R. 1993. Non-parametric multivariate analyses of changes in community structure. Austral Ecology 18:117-143. http://dx.doi.org/10.1111/j.1442-9993.1993.tb00438.x

Cramp, S., and K. E. L. Simmons. 1980. Handbook of the birds of Europe, the Middle East and North Africa. Oxford University Press, Oxford, UK.

De Frutos, A., P. P. Olea, and P. Mateo-Tomás. 2015. Responses of medium- and large-sized bird diversity to irrigation in dry cereal agroecosystems across spatial scales. Agriculture, Ecosystems \& Environment 207:141-152. http://dx.doi.org/10.1016/ j.agee.2015.04.009

Delgado, M. P., J. Traba, E. L. García de la Morena, and M. B. Morales. 2010. Habitat selection and density-dependent relationships in spatial occupancy by male Little Bustards Tetrax tetrax. Ardea 98:185-194. http://dx.doi.org/10.5253/078.098.0208

ESRI. 2014. ArcInfo desktop GIS. ArcMap 10.2.2, Redlands, California.

Freschi, P., S. Fascetti, M. Musto, E. Mallia, A. C. Blasi, C. Cosentino, and R. Paolino. 2014. Diet of the Apennine hare in a southern Italy Regional Park. European Journal of Wildlife Research 60:423-430. http://dx.doi.org/10.1007/s10344-014-0799y

Fry, D. M. 1995. Reproductive effects in birds exposed to pesticides and industrial-chemicals. Environmental Health Perspectives 103:165-171.

García de la Morena, E. 2016. Ecología y movimientos migratorios del sisón común (Tetrax tetrax) fuera del período reproductor. Universidad Autónoma de Madrid, Madrid, Spain.

García de la Morena, E., G. Bota, A. Ponjoan, and M. B. Morales. 2006. El sisón común en España. I censo Nacional. SEO/BirdLife, Madrid, Spain.

García de la Morena, E., M. B. Morales, E. De Juana, and F. Suárez. 2007. Surveys of wintering Little Bustards Tetrax tetrax in central Spain: distribution and population estimates at a regional scale. Bird Conservation International 17:23-34. http://dx. doi.org/10.1017/S0959270906000608 
Goriup, P. D. 1994. Little Bustard Tetrax tetrax. Pages 236-237 in G. M. Tucker, M. F. Heath, L. Tomialojc, and R. F. A. Grimmett, editors editor. Birds in Europe: their conservation status. BirdLife International, Cambridge, UK.

Iñigo, A., and A. Barov. 2010. Action plan for the Little Bustard Tetrax tetrax in the European Union. SEO|BirdLife and BirdLife International for the European Commission, Cambridge, UK.

Jiguet, F. 2002. Arthropods in diet of Little Bustards Tetrax tetrax during the breeding season in western France. Bird Study 49:105-109. http://dx.doi.org/10.1080/00063650209461253

Kobayashi, K., and S. Takatsuki. 2012. A comparison of food habits of two sympatric ruminants of Mt. Yatsugatake, central Japan: sika deer and Japanese serow. Acta Theriologica 57:343-349. http://dx.doi.org/10.1007/s13364-012-0077-x

Kovács-Hostyánszki, A., and A. Báldi. 2012. Set-aside fields in agri-environment schemes can replace the market-driven abolishment of fallows. Biological Conservation 152:196-203. http://dx.doi.org/10.1016/j.biocon.2012.03.039

Kruskal, J. B. 1964. Multidimensional scaling by optimizing goodness of fit to a nonmetric hypothesis. Psychometrika 29:1-27. http://dx.doi.org/10.1007/BF02289565

La Morgia, V., and B. Bassano. 2009. Feeding habits, forage selection, and diet overlap in Alpine chamois (Rupicapra rupicapra L.) and domestic sheep. Ecological Research 24:1043-1050. http://dx.doi.org/10.1007/s11284-008-0581-2

Lane, S. J., J. C. Alonso, J. A. Alonso, and M. A. Naveso. 1999. Seasonal changes in diet and diet selection of Great Bustards (Otis t. tarda) in north-west Spain. Journal of Zoology 247:201-214. http://dx.doi.org/10.1111/j.1469-7998.1999.tb00984.x

Lefcheck, J. S., M. A. Whalen, T. M. Davenport, J. P. Stone, and J. E. Duffy. 2013. Physiological effects of diet mixing on consumer fitness: a meta-analysis. Ecology 94:565-572. http://dx.doi. org/10.1890/12-0192.1

Lemly, A. D., R. T. Kingsford, and J. R. Thompson. 2000. Irrigated agriculture and wildlife conservation: conflict on a global scale. Environmental Management 25:485-512. http://dx. doi.org/10.1007/s002679910039

Martínez, C. 1994. Habitat selection by the Little Bustard Tetrax tetrax in cultivated areas of central Spain. Biological Conservation 67:125-128. http://dx.doi.org/10.1016/0006-3207(94)90357-3

Martínez, C. 2008. Sisón común - Tetrax tetrax. In A. Salvadorand M. B. Morales, editors. Enciclopedia Virtual de los Vertebrados Españoles. Museo Nacional de Ciencias Naturales, Madrid, Spain. [online] URL: http://www.vertebradosibericos. org/aves/tettet.html

McCune, B., and J. B. Grace. 2002. Analysis of ecological communities. MjM Software Design, Gleneden Beach, Oregon, USA.

McGarigal, K., S. A. Cushman, and E. Ene. 2012. FRAGSTATS v4: spatial pattern analysis program for categorical and continuous maps. University of Massachusetts, Amherst, Massachusetts, USA. [online] URL: http://www.umass.edu/landeco/research/ fragstats/fragstats.html
Moorcroft, D., J. D. Wilson, and R. B. Bradbury. 2006. Diet of nestling Linnets Carduelis cannabina on lowland farmland before and after agricultural intensification. Bird Study 53:156-162. http://dx.doi.org/10.1080/00063650609461428

Morales, M. B., J. Traba, and B. Arroyo. 2015. El declive del sisón en el centro de España. Quercus 356:36-43.

Morales, M. B., J. Traba, E. Carriles, M. P. Delgado, and E. L. García de la Morena. 2008. Sexual differences in microhabitat selection of breeding Little Bustards Tetrax tetrax: ecological segregation based on vegetation structure. Acta Oecologica 34:345-353. http://dx.doi.org/10.1016/j.actao.2008.06.009

Morales, M. B., J. Traba, M. P. Delgado, and E. L. García de la Morena. 2013. The use of fallows by nesting Little Bustard Tetrax tetrax females: implications for conservation in mosaic cereal farmland. Ardeola 60:85-97. http://dx.doi.org/10.13157/arla.60.1.2012.85

Oksanen, J., F. G. Blanchet, R. Kindt, P. Legendre, P. R. Minchin, R. B. O'Hara, G. L. Simpson, P. Solymos, M. H. H. Stevens, and H. Wagner. 2013. vegan: Community ecology package. R package version 2.0-9. The R Project for Statistical Computing, Vienna, Austria. http://CRAN.R-project.org/package=vegan

Ottens, H. J., M. W. Kuiper, H. Flinks, J. V. Ruijven, H. Siepel, B. J. Koks, F. Berendse, and G. R. de Snoo. 2014. Do field margins enrich the diet of the Eurasian Skylark Alauda arvensis on intensive farmland? Ardea 102:161-174. http://dx.doi.org/10.5253/ arde.v102i2.a6

Ponce, C., C. Bravo, and J. C. Alonso. 2014. Effects of agrienvironmental schemes on farmland birds: do food availability measurements improve patterns obtained from simple habitat models? Ecology and Evolution 4:2834-2847. http://dx.doi. org/10.1002/ece3.1125

Ponjoan, A., G. Bota, and S. Mañosa. 2012. Ranging behaviour of Little Bustard males, Tetrax tetrax, in the lekking grounds. Behavioural Processes 91:35-40. http://dx.doi.org/10.1016/j. beproc.2012.05.005

Raubenheimer, D., and S. J. Simpson. 1997. Integrative models of nutrient balancing: application to insects and vertebrates. Nutritional Research Reviews 10:151-179. http://dx.doi. org/10.1079/NRR19970009

Salamolard, M., and C. Moreau. 1999. Habitat selection by Little Bustard Tetrax tetrax in a cultivated area of France. Bird Study 46:25-33. http://dx.doi.org/10.1080/00063659909461112

Saunders, D. A., R. J. Hobbs, and C. R. Margules. 1991. Biological consequences of ecosystem fragmentation: a review. Conservation Biology 5:18-32. http://dx.doi.org/10.1111/j.1523-1739.1991. tb00384.x

Shlyakhtin, G. V., V. G. Tabachishin, A. V. Khrustov, and E. V. Zav'yalov. 2004. Ecological segregation of bustards (Otididae) in the North of the Lower Volga region: evolutionary and adaptive aspects. Russian Journal of Ecology 35:247-253. http://dx.doi. org/10.1023/B:RUSE.0000033794.84672.de

Silva, J. P., N. Faria, and T. Catry. 2007. Summer habitat selection and abundance of the threatened Little Bustard in Iberian agricultural landscapes. Biological Conservation 139:186-194. http://dx.doi.org/10.1016/j.biocon.2007.06.013 
Silva, J. P., M. Pinto, and J. M. Palmeirim. 2004. Managing landscapes for the Little Bustard Tetrax tetrax: lessons from the study of winter habitat selection. Biological Conservation 117:521-528. http://dx.doi.org/10.1016/j.biocon.2003.09.001

Smith, L. W., H. K. Goering, and C. H. Gordon. 1972. Relationships of forage compositions with rates of cell-wall digestion and indigestibility of cell-walls. Journal of Dairy Science 55:1140-1147. http://dx.doi.org/10.3168/jds.s0022-0302(72)85636-4

Stephens, D. W., and J. R. Krebs. 1986. Foraging theory. Princeton University Press, Princeton, New Jersey, USA.

Tarjuelo, R., M. P. Delgado, G. Bota, M. B. Morales, J. Traba, A. Ponjoan, I. Hervás, and S. Mañosa. 2013. Not only habitat but also sex: factors affecting spatial distribution of Little Bustard Tetrax tetrax families. Acta Ornithologica 48:119-128. http://dx. doi.org/10.3161/000164513X670070

Tella, J. L., and M. G. Forero. 2000. Farmland habitat selection of wintering Lesser Kestrels in a Spanish pseudosteppe: implications for conservation strategies. Biodiversity and Conservation 9:433-441. http://dx.doi.org/10.1023/A:1008943116150

Traba, J., M. B. Morales, E. L. García de la Morena, M. P. Delgado, and A. Krištín. 2008. Selection of breeding territory by Little Bustard (Tetrax tetrax) males in central Spain: the role of arthropod availability. Ecological Research 23:615-622. http://dx. doi.org/10.1007/s11284-007-0418-4

Ursúa, E., D. Serrano, and J. L. Tella. 2005. Does land irrigation actually reduce foraging habitat for breeding lesser kestrels? The role of crop types. Biological Conservation 122:643-648. http://dx. doi.org/10.1016/j.biocon.2004.10.002

Vavra, M., and J. L. Holechek. 1980. Factors influencing microhistological analysis of herbivore diets. Journal of Range Management 33:371-374. http://dx.doi.org/10.2307/3897886

Whitney, L. W., R. G. Anthony, and D. H. Jackson. 2011. Resource partitioning between sympatric Columbian white-tailed and black-tailed deer in Western Oregon. Journal of Wildlife Management 75:631-645. http://dx.doi.org/10.1002/jwmg.78

Wolff, A., T. Dieuleveut, J.-L. Martin, and V. Bretagnolle. 2002. Landscape context and Little Bustard abundance in a fragmented steppe: implications for reserve management in mosaic landscapes. Biological Conservation 107:211-220. http://dx.doi. org/10.1016/S0006-3207(02)00087-3

Wolff, A., J.-P. Paul, J. L. Martin, and V. Bretagnolle. 2001. The benefits of extensive agriculture to birds: the case of the Little Bustard. Journal of Applied Ecology 38:963-975. http://dx.doi. org/10.1046/j.1365-2664.2001.00651.X

Xu, W., C. Xia, J. Lin, W. Yang, D. A. Blank, J. Qiao, and W. Liu. 2012. Diet of Gazella subgutturosa (Guldenstaedt, 1780) and food overlap with domestic sheep in Xinjiang, China. Folia Zoologica 61:54-60.

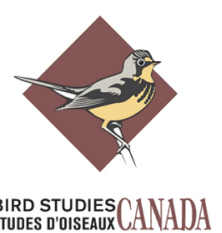


Appendix 1: Supplemental material for the paper "Diet composition of a declining steppe bird, the Little bustard (Tetrax tetrax), in relation to farming practices" by Carolina Bravo, Francesc Cuscó, Manuel B. Morales and Santi Mañosa

Table A1. 1. Diet diversity $\left(\mathrm{H}^{\prime}\right)$ and green plant families identified in Little Bustard diet sorted by irrigated and dry farmland area. Diet composition is shown as the average $( \pm \mathrm{SD})$ percentage of microscope fields with presence of each family per dropping. Infrequent families (Caryophyllaceae, Boraginaceae, Dipsacaceae, Euphorbiaceae, Malvaceae, Plantaginaceae, Primulaceae, Resedaceae, Rubiaceae, Scrophulariaceae) are grouped in "other" category. $N$ represents the total number of collected droppings and Date represents date of collection.

\begin{tabular}{|c|c|c|c|c|c|c|c|c|c|c|c|c|c|}
\hline & Date & $\mathbf{N}$ & $\begin{array}{c}\text { Diversity } \\
\left(\mathbf{H}^{\prime}\right)\end{array}$ & $\begin{array}{c}\text { Cultivated } \\
\text { legumi- } \\
\text { nosae }(\%)\end{array}$ & $\begin{array}{c}\text { Weedy } \\
\text { legumi- } \\
\text { nosae }(\%)\end{array}$ & $\begin{array}{c}\text { Cultivated } \\
\text { gramineae } \\
(\%)\end{array}$ & $\begin{array}{c}\text { Weedy } \\
\text { gramineae } \\
(\%)\end{array}$ & $\begin{array}{c}\text { Papave- } \\
\text { raceae } \\
(\%)\end{array}$ & $\begin{array}{c}\text { Compositae } \\
(\%)\end{array}$ & $\begin{array}{c}\text { Cruciferae } \\
(\%)\end{array}$ & $\begin{array}{c}\text { Convolvu- } \\
\text { laceae } \\
(\%)\end{array}$ & $\begin{array}{c}\text { Labiatae } \\
(\%)\end{array}$ & $\begin{array}{c}\text { Other } \\
(\%)\end{array}$ \\
\hline Irrigated area & & 138 & $0.6 \pm 0.2$ & $67.0 \pm 28.4$ & $0.1 \pm 0.1$ & $0.7 \pm 1.7$ & $0.9 \pm 1.1$ & $1.2 \pm 1.6$ & $2.0 \pm 2.4$ & $25.2 \pm 25.5$ & $0.1 \pm 0.5$ & $1.4 \pm 3.4$ & $1.5 \pm 2.1$ \\
\hline 1. Anglesola & Jan. 2013 & 20 & $0.4 \pm 0.3$ & $86.7 \pm 11.5$ & & $0.5 \pm 2.1$ & & & $0.1 \pm 0.3$ & $9.3 \pm 8.3$ & & $2.4 \pm 3.8$ & $1.1 \pm 2.3$ \\
\hline 2. Arbeca & Nov/Dec. 2011/12 & 20 & $0.8 \pm 0.2$ & $60.6 \pm 14.2$ & $0.2 \pm 0.6$ & $0.1 \pm 0.3$ & & $0.4 \pm 0.9$ & $3.9 \pm 3.9$ & $31.8 \pm 14.8$ & $0.4 \pm 1.1$ & $0.7 \pm 2.9$ & $2.1 \pm 4.1$ \\
\hline 3. Castellnou S. & Jan. 2012 & 10 & $0.3 \pm 0.3$ & $90.0 \pm 10.6$ & & $4.9 \pm 9.6$ & $0.1 \pm 0.4$ & $0.2 \pm 0.8$ & & $3.3 \pm 5.2$ & & $1.2 \pm 1.5$ & $0.2 \pm 0.5$ \\
\hline 4. Torregrossa & Dec. 2011 & 10 & $0.7 \pm 0.4$ & $79.1 \pm 12.7$ & $0.8 \pm 1.6$ & & & $1.7 \pm 2.9$ & $0.1 \pm 0.4$ & $9.3 \pm 5.5$ & $0.1 \pm 0.4$ & $8.0 \pm 5.3$ & $1.0 \pm 1.2$ \\
\hline 5. Miralcamp & Nov. 2011 & 13 & $0.6 \pm 0.4$ & $0.8 \pm 2.0$ & $0.3 \pm 0.5$ & $0.1 \pm 0.4$ & $2.5 \pm 4.6$ & $2.6 \pm 7.0$ & $5.2 \pm 5.5$ & $83.9 \pm 12.8$ & $0.3 \pm 0.8$ & $3.0 \pm 5.0$ & $1.3 \pm 1.6$ \\
\hline 6. El Poal & Nov. 2013 & 10 & $0.8 \pm 0.2$ & $68.4 \pm 10.6$ & & & $1.6 \pm 4.9$ & $4.3 \pm 5.2$ & $1.4 \pm 2.5$ & $23.9 \pm 7.9$ & & & $0.5 \pm 1.1$ \\
\hline 7. Sidamon & Jan. 2012 & 10 & $0.7 \pm 0.5$ & $72.4 \pm 30.7$ & & & $2.3 \pm 6.4$ & $0.0 \pm 0.0$ & $5.5 \pm 4.7$ & $18.0 \pm 20.0$ & & $0.2 \pm 0.5$ & $1.7 \pm 2.9$ \\
\hline 8. La Puebla de M. & Dec/Jan. 2003/05 & 45 & $0.5 \pm 0.3$ & $77.3 \pm 13.2$ & $0.0 \pm 0.1$ & & $0.5 \pm 0.9$ & $0.1 \pm 0.4$ & $0.0 \pm 0.3$ & $21.8 \pm 12.7$ & & $0.2 \pm 0.5$ & $0.1 \pm 0.2$ \\
\hline Dryland area & & 219 & $1.3 \pm 0.4$ & $26.5 \pm 28.4$ & $2.0 \pm 4.2$ & $11.0 \pm 10.6$ & $2.8 \pm 2.5$ & $8.3 \pm 19.2$ & $16.3 \pm 15.2$ & $21.6 \pm 15.1$ & $1.5 \pm 5.1$ & $6.3 \pm 13.2$ & $3.9 \pm 3.4$ \\
\hline 9. C. de Calatrava & Dec. 2011 & 84 & $1.7 \pm 0.3$ & $15.4 \pm 14.7$ & $12.0 \pm 10.4$ & $0.0 \pm 0.2$ & $1.3 \pm 1.4$ & $9.4 \pm 9.5$ & $29.3 \pm 20.7$ & $23.0 \pm 17.2$ & $1.6 \pm 4.5$ & $4.9 \pm 9.7$ & $3.2 \pm 3.8$ \\
\hline 10. Campo Real & Nov. 2012 & 8 & $1.7 \pm 0.2$ & $20.8 \pm 20.0$ & & $0.2 \pm 0.4$ & $7.0 \pm 3.8$ & $0.2 \pm 0.4$ & $1.9 \pm 2.1$ & $35.0 \pm 11.1$ & $1.0 \pm 0.9$ & $27.9 \pm 16.3$ & $6.1 \pm 7.4$ \\
\hline 11. Valdepiélagos & Jan. 2012 & 15 & $0.7 \pm 0.2$ & $69.6 \pm 16.0$ & & $26.8 \pm 16.9$ & $0.9 \pm 1.4$ & & $0.9 \pm 2.6$ & $0.2 \pm 0.6$ & & $0.2 \pm 0.4$ & $1.6 \pm 3.1$ \\
\hline 12. Cobeña & Dec. 2011 & 10 & $1.3 \pm 0.3$ & $0.4 \pm 0.8$ & $3.2 \pm 3.0$ & $22.3 \pm 16.5$ & $1.5 \pm 2.2$ & & $21.8 \pm 17.4$ & $47.1 \pm 15.9$ & $2.6 \pm 4.5$ & $0.1 \pm 0.4$ & $1.1 \pm 0.8$ \\
\hline 13. Daganzo de A. & Jan. 2011 & 17 & $1.2 \pm 0.2$ & $1.5 \pm 6.4$ & $0.3 \pm 0.7$ & $14.6 \pm 10.3$ & $0.8 \pm 1.6$ & $55.2 \pm 12.6$ & $15.8 \pm 12.6$ & $9.5 \pm 9.9$ & $0.1 \pm 0.6$ & $0.5 \pm 1.2$ & $1.7 \pm 2.9$ \\
\hline 14. Valdetorres J. & Jan. 2010 & 25 & $0.9 \pm 0.4$ & $70.6 \pm 23.2$ & & & $4.7 \pm 5.4$ & & $7.3 \pm 8.5$ & $13.7 \pm 15.2$ & & $3.2 \pm 6.3$ & $0.6 \pm 2.0$ \\
\hline 15. Villanueva $\mathrm{T}$. & Dec/Jan. 2011/13 & 54 & $1.2 \pm 0.4$ & $25.9 \pm 23.9$ & $0.6 \pm 3.3$ & $16.0 \pm 25.6$ & $5.5 \pm 7.6$ & $0.6 \pm 2.2$ & $8.1 \pm 8.7$ & $28.6 \pm 26.5$ & $0.4 \pm 1.3$ & $13.2 \pm 19.5$ & $1.1 \pm 2.2$ \\
\hline 16. T. de Velasco & Nov. 2012 & 6 & $1.4 \pm 0.2$ & $7.3 \pm 8.2$ & & $7.9 \pm 6.0$ & $1.0 \pm 1.9$ & $1.2 \pm 1.5$ & $45.0 \pm 22.6$ & $15.5 \pm 8.2$ & $21.8 \pm 16.2$ & & $0.2 \pm 0.5$ \\
\hline TOTAL & & 357 & $0.9 \pm 0.4$ & $46.7 \pm 34.5$ & $1.0 \pm 3.0$ & $5.8 \pm 9.0$ & $1.9 \pm 2.1$ & $4.7 \pm 13.7$ & $9.1 \pm 12.8$ & $23.4 \pm 20.3$ & $1.8 \pm 5.4$ & $4.1 \pm 7.3$ & $1.5 \pm 1.5$ \\
\hline
\end{tabular}


Table A1.2. Plant species identified in Little Bustard diet sorted by irrigated $(n=8)$ and dry $(n=8)$ farmland areas. Frequency of each plant species is expressed as the average percentage $( \pm \mathrm{SD})$ of droppings in which the species appears, and diet composition is shown as the average $( \pm \mathrm{SD})$ percentage of microscope fields with presence of each species per dropping. Averages were based on the mean of the 8 sampling sites per agroecosystem.

\begin{tabular}{|c|c|c|c|c|c|}
\hline \multirow[b]{2}{*}{ Family } & \multirow[b]{2}{*}{ Species } & \multicolumn{2}{|c|}{ Frequency $(\%)$} & \multicolumn{2}{|c|}{ Diet composition (\%) } \\
\hline & & Irrigated area & $\begin{array}{c}\text { Dry farmland } \\
\text { area }\end{array}$ & Irrigated area & $\begin{array}{c}\text { Dry farmland } \\
\text { area }\end{array}$ \\
\hline \multirow[t]{4}{*}{ Boraginaceae } & Echium plantagineum & & $4.0 \pm 9.3$ & & $0.17 \pm 0.39$ \\
\hline & Heliotropium europaeum & & $0.1 \pm 0.4$ & & \\
\hline & Lithospermum apulum & $1.3 \pm 3.3$ & $0.7 \pm 2.1$ & $0.04 \pm 0.12$ & $0.01 \pm 0.02$ \\
\hline & Lithospermum arvensis & $1.7 \pm 3.6$ & $1.2 \pm 2.3$ & $0.05 \pm 0.14$ & $0.09 \pm 0.16$ \\
\hline Caryophyllaceae & Stellaria media & $1.3 \pm 3.3$ & $7.4 \pm 18.8$ & $0.03 \pm 0.08$ & $0.14 \pm 0.34$ \\
\hline \multirow[t]{15}{*}{ Compositae } & Anacyclus clavatus & $28.2 \pm 29.2$ & $58.3 \pm 42.6$ & $1.68 \pm 2.00$ & $11.53 \pm 15.06$ \\
\hline & Andryala integrifolia & & $25.4 \pm 28.4$ & & $2.62 \pm 4.30$ \\
\hline & Bellis perennis & $0.6 \pm 1.7$ & & $0.01 \pm 0.02$ & \\
\hline & Calendula arvensis & & $0.2 \pm 0.7$ & & $0.00 \pm 0.01$ \\
\hline & Carthamus lanatus & & $6.7 \pm 11.8$ & & $0.16 \pm 0.34$ \\
\hline & Cnicus benedictus & & $2.1 \pm 5.9$ & & $0.12 \pm 0.35$ \\
\hline & Crepis sancta & & $0.4 \pm 1.3$ & & $0.00 \pm 0.01$ \\
\hline & Crepis vesicaria & $1.4 \pm 3.7$ & $11.8 \pm 16.0$ & $0.03 \pm 0.09$ & $0.30 \pm 0.44$ \\
\hline & Filago sp & & $7.0 \pm 13.4$ & & $0.65 \pm 1.71$ \\
\hline & Picris echinoides & & $19.7 \pm 25.7$ & & $0.53 \pm 0.67$ \\
\hline & Picris $s p$ & & $1.9 \pm 4.2$ & & $0.04 \pm 0.09$ \\
\hline & Senecio vulgaris & $2.5 \pm 4.3$ & $0.1 \pm 0.4$ & $0.03 \pm 0.06$ & $0.00 \pm 0.01$ \\
\hline & Silybum marianum & $0.3 \pm 0.7$ & $0.5 \pm 1.0$ & $0.00 \pm 0.01$ & $0.01 \pm 0.02$ \\
\hline & Tolpis barbata & & $0.1 \pm 0.4$ & & $0.01 \pm 0.02$ \\
\hline & Undetermined & $7.0 \pm 13.0$ & $9.1 \pm 20.4$ & $0.60 \pm 1.07$ & $3.30 \pm 4.09$ \\
\hline Convolvulaceae & Convolvulus arvensis & $3.9 \pm 5.0$ & $35.0 \pm 36.2$ & $0.09 \pm 0.14$ & $3.45 \pm 7.48$ \\
\hline \multirow[t]{2}{*}{ Cruciferae } & Alyssum minus & & $0.9 \pm 2.5$ & & $0.03 \pm 0.08$ \\
\hline & Biscutella auriculata & & $9.7 \pm 21.7$ & & $1.11 \pm 2.59$ \\
\hline
\end{tabular}




\begin{tabular}{|c|c|c|c|c|c|}
\hline \multirow[b]{2}{*}{ Family } & \multirow[b]{2}{*}{ Species } & \multicolumn{2}{|c|}{ Frequency $(\%)$} & \multicolumn{2}{|c|}{ Diet composition (\%) } \\
\hline & & Irrigated area & $\begin{array}{c}\text { Dry farmland } \\
\text { area }\end{array}$ & Irrigated area & $\begin{array}{c}\text { Dry farmland } \\
\text { area }\end{array}$ \\
\hline & Brassica repanda & & $0.1 \pm 0.4$ & & $0.02 \pm 0.05$ \\
\hline & Camelina micrarpa & $1.3 \pm 3.3$ & & $0.01 \pm 0.04$ & \\
\hline & Capsella bursa-pastoris & $91.1 \pm 7.8$ & $42.3 \pm 24.5$ & $24.34 \pm 25.62$ & $5.24 \pm 5.88$ \\
\hline & Cardaria draba & & $3.1 \pm 8.8$ & & $0.64 \pm 1.80$ \\
\hline & Descurainia sophia & $0.3 \pm 0.7$ & $0.7 \pm 2.1$ & $0.00 \pm 0.01$ & $0.01 \pm 0.03$ \\
\hline & Diplotaxis erucoides & & $36.6 \pm 38.5$ & & $8.47 \pm 15.89$ \\
\hline & Malcolmia africana & & $0.1 \pm 0.4$ & & \\
\hline & Neslia paniculata & & $13.4 \pm 19.6$ & & $1.77 \pm 3.69$ \\
\hline & Raphanus raphanistrum & & $2.9 \pm 4.5$ & & $0.27 \pm 0.48$ \\
\hline & Sisymbrium irio & $4.5 \pm 6.9$ & $3.6 \pm 6.8$ & $0.20 \pm 0.45$ & $0.71 \pm 1.35$ \\
\hline & Undetermined & $20.1 \pm 26.3$ & $26.9 \pm 32.3$ & $0.22 \pm 0.50$ & $0.64 \pm 1.67$ \\
\hline \multirow[t]{2}{*}{ Dipsacaceae } & Scabiosa sp & & $3.2 \pm 5.1$ & & $0.06 \pm 0.11$ \\
\hline & Scabiosa stellata & $1.3 \pm 3.3$ & $0.2 \pm 0.7$ & $0.02 \pm 0.06$ & $0.00 \pm 0.01$ \\
\hline Euphorbiaceae & Euphorbia helioscopia & & $0.5 \pm 1.4$ & & $0.03 \pm 0.08$ \\
\hline Geraniaceae & Undetermined & $3.8 \pm 7.0$ & $8.0 \pm 17.7$ & $0.09 \pm 0.18$ & $1.86 \pm 2.53$ \\
\hline \multirow[t]{7}{*}{ Gramineae } & Bromus diandrus & & $2.4 \pm 4.5$ & & $0.09 \pm 0.22$ \\
\hline & Bromus sp & & $0.7 \pm 2.1$ & & $0.02 \pm 0.05$ \\
\hline & Hordeum murinum & $6.9 \pm 18.4$ & $32.4 \pm 11.8$ & $0.31 \pm 0.89$ & $0.84 \pm 0.38$ \\
\hline & Hordeum vulgare & $2.6 \pm 3.8$ & $55.5 \pm 44.5$ & $0.08 \pm 0.17$ & $10.79 \pm 10.40$ \\
\hline & Lolium rigidum & $3.8 \pm 7.0$ & $0.7 \pm 2.1$ & $0.46 \pm 0.87$ & $0.01 \pm 0.04$ \\
\hline & Triticum aestivum & $3.8 \pm 9.9$ & $1.5 \pm 2.8$ & $0.61 \pm 1.73$ & $0.18 \pm 0.35$ \\
\hline & Undetermined & $6.9 \pm 11.6$ & $27.9 \pm 34.8$ & $0.01 \pm 0.02$ & $0.00 \pm 0.01$ \\
\hline Labiatae & Lamium amplexicaule & $32.8 \pm 27.7$ & $34.4 \pm 33.0$ & $1.95 \pm 2.67$ & $6.24 \pm 9.83$ \\
\hline \multirow[t]{4}{*}{ Leguminosae } & Astragalus hamosus & & $10.3 \pm 29.0$ & & $1.16 \pm 3.27$ \\
\hline & Astragalus sp & $2.8 \pm 7.3$ & & $0.03 \pm 0.09$ & \\
\hline & Medicago polymorpha & $2.5 \pm 6.6$ & & $0.03 \pm 0.08$ & \\
\hline & Medicago sativa & $89.0 \pm 25.5$ & & $66.90 \pm 28.34$ & \\
\hline
\end{tabular}




\begin{tabular}{|c|c|c|c|c|c|}
\hline \multirow[b]{2}{*}{ Family } & \multirow[b]{2}{*}{ Species } & \multicolumn{2}{|c|}{ Frequency $(\%)$} & \multicolumn{2}{|c|}{ Diet composition (\%) } \\
\hline & & Irrigated area & $\begin{array}{c}\text { Dry farmland } \\
\text { area }\end{array}$ & Irrigated area & $\begin{array}{c}\text { Dry farmland } \\
\text { area }\end{array}$ \\
\hline & Medicago $s p$ & & $37.2 \pm 28.3$ & & $5.39 \pm 7.63$ \\
\hline & Ornithopus compressus & & $11.9 \pm 27.7$ & & $0.48 \pm 1.10$ \\
\hline & Trifolium angustifolium & & $3.5 \pm 7.1$ & & $0.04 \pm 0.07$ \\
\hline & Trigonella monspeliaca & $0.3 \pm 0.7$ & $9.4 \pm 26.5$ & $0.00 \pm 0.01$ & $0.31 \pm 0.89$ \\
\hline & Vicia sativa & & $25.0 \pm 45.1$ & & $17.15 \pm 31.39$ \\
\hline & Vicia sp & $3.8 \pm 7.0$ & $24.0 \pm 30.4$ & $0.10 \pm 0.21$ & $3.91 \pm 6.22$ \\
\hline Malvaceae & Malva sylvestris & & $3.5 \pm 5.1$ & & $0.04 \pm 0.06$ \\
\hline \multirow{2}{*}{ Papaveraceae } & Papaver hybridum & & $6.3 \pm 17.7$ & & $0.15 \pm 0.42$ \\
\hline & Papaver rhoeas & $24.4 \pm 23.3$ & $27.6 \pm 43.6$ & $1.17 \pm 1.58$ & $8.17 \pm 19.29$ \\
\hline Plantaginaceae & Plantago lagopus & $0.9 \pm 1.7$ & $1.2 \pm 2.3$ & $0.02 \pm 0.06$ & $0.01 \pm 0.02$ \\
\hline Primulaceae & Anagallis arvensis & & $0.2 \pm 0.7$ & & $0.01 \pm 0.02$ \\
\hline Resedaceae & Reseda alba & & $0.3 \pm 0.8$ & & $0.01 \pm 0.02$ \\
\hline \multirow[t]{2}{*}{ Rubiaceae } & Galium tricornutum & & $4.0 \pm 11.4$ & & $0.11 \pm 0.31$ \\
\hline & Sherardia arvensis & & $0.3 \pm 0.8$ & & $0.00 \pm 0.01$ \\
\hline \multirow[t]{2}{*}{ Scrophulariaceae } & Veronica heredifolia & $6.3 \pm 10.2$ & $15.6 \pm 18.3$ & $0.13 \pm 0.20$ & $0.29 \pm 0.36$ \\
\hline & Veronica polita & $1.4 \pm 3.7$ & $0.1 \pm 0.4$ & $0.02 \pm 0.05$ & \\
\hline Undetermined & Undetermined & $20.6 \pm 13.0$ & $12.3 \pm 10.3$ & $0.26 \pm 0.62$ & $0.29 \pm 0.69$ \\
\hline
\end{tabular}

